\title{
Bio-management of Meloidogyne incognita in Pumpkin
}

\author{
Pc. Lalhruaitluanga* and Koilash Hazarika \\ Department of Nematology, Assam Agricultural University, Jorhat, Assam- 785013, India \\ *Corresponding author
}

\begin{tabular}{l} 
Ke y w or d s \\
Trichoderma \\
harzianum, \\
Mustard cake and \\
M. incognita \\
\hline Article Info \\
\hline $\begin{array}{l}\text { Accepted: } \\
\text { 07 October } 2020 \\
\text { Available Online: } \\
10 \text { November } 2020\end{array}$ \\
\hline
\end{tabular}

Keywords

Trichoderma harzianum,

Mustard cake and M. incognito

Accepted:

07 October 2020

10 November 2020

\section{A B S T R A C T}

\begin{abstract}
A field experiment was carried out during the rabi season of 2019-20 in the Instructionalcum-Research Farm, Assam Agricultural University, Jorhat for the management of $M$. incognita on Pumpkin. Pumpkin cultivar Karbi-I, was selected for the present investigation. The experiment was conducted in randomized block design with five treatments like T1- Trichoderma harzianum @ $20 \mathrm{~kg} / \mathrm{ha}$ at time of sowing, T2- Mustard cake@ $950 \mathrm{~kg} / \mathrm{ha}$ applied 15 days prior to sowing, T3- Trichoderma harzianum @ 10 $\mathrm{kg} / \mathrm{ha}$ at time of sowing + Mustard cake @ $375 \mathrm{~kg} / \mathrm{ha}$ applied 15 days prior to sowing, T4Carbofuran@ @ $1 \mathrm{~kg}$ ai/ ha and T5- Control. Area of the experimental plot was divided in to 20 plots measuring $6 \mathrm{~m} \times 3 \mathrm{~m}\left(18 \mathrm{~m}^{2}\right)$ in each plot with four rows. The results of the field studies revealed that all the treatments were found to be effective in increasing the overall plant growth, number of fruits per plot and yield per plot of pumpkin over control. Carbofuran @ $1 \mathrm{~kg}$ ai/ha gave the best result in respect of yield (155.12 q/ha) as well as reducing the nematode infestation (59.67 i.e number of galls and 46.70 i.e. number of galls). Combined application of Mustard cake and Trichoderma harzianum at applied doses brought about a significant reduction in number of galls (63.333), egg masses (56.42) and final nematode population (235.05 per 200cc of soil) in soil with increased yield ( $140.07 \mathrm{q} / \mathrm{ha}$ ) compared to control. Among the bio treatments for management of $M$. incognita under field condition, combined treatments Trichoderma harzianum and Mustard cake was found to be the best so far as yield of pumpkin and reduction of nematode population is concern.
\end{abstract}

\section{Introduction}

Pumpkin belongs to the family Cucurbitaceae. Pumpkin (Cucurbita pepo) is a climber as well as trailer and able to complete their life cycle within one growing season. Some other members of this family are cucumber, gherkin, sponge gourd, ridge gourd, ash gourd, pointed gourd, snake gourd, bitter gourd, long melon etc. It is rich in polyphenolics, antioxidants and flavonoids including lutein and both alpha and beta carotene, the latter of which generates vitamin $\mathrm{A}$ in the body. The plants belong to this family are highly susceptible to numerous pest and diseases. Among them root knot nematode were first discovered as a pest of cucumber by Berkeley in 1855 at England. It was reported that root knot nematode feed on more than 3000 hosts plants and globally it destroys 29-30 per cent of vegetable crops. However, in Assam, it caused 17.92 per cent 
of an avoidable yield loss in the cucumber (Anonymous, 2011). In India, 76,000 ha area of pumpkin are treated with pesticides for the control of its pest and diseases (Anonymous, 2018) but, application of pesticides cause's environmental hazards. Pesticides are reported to have detrimental effects on human, animals, plant, beneficial microorganisms etc. and also known for residual effect in the soil. Apart from chemical control, evaluation of different cultivar against target pathogen will helps in identifying the resistance cultivar and use of such cultivar is also one of the promising ways of managing nematodes which is safe in concern with environment. However, the degree of damage done also depends upon the density of the nematode, reaction of crop to pathogen and environmental condition such as fertility, moisture and presence of other pathogenic organisms, which may interact with plant parasitic nematodes. There are various methods of controlling plant parasitic nematodes but the application of biocontrol agents in combination with organic manure either control the pathogen or give better plant growth as well as yield. Further, it doesn't show any harmful effects on the environment including beneficial microorganisms. The efficacy of bioagents is varied from species to species (Irving and Kerry, 1986). The application of native biocontrol agents is found to be beneficial because they are ecologically adapted with their host and give better plant protection against pathogen in the immediate vicinity of host plant those results in better growth and development of plant. The bioagents are highly rhizosphere competent with pathogen and showed several mechanisms like antibiosis, parasitism, predation etc against pathogen (Kalita, 2010 and Anapurna et al., 2018 and Kurulkar et al., 2019). However, their colonization not only reduced their density but also enhance the growth parameters of plant. Application of organic manures reduces pathogen inoculum level by release of toxic substance during decomposition and enhances the growth of natural enemies in soil (Rodriguez-Kabana et al., 1986). However, eco-friendly management plays an important role in integrated nematode management programme due to adverse effect chemical pesticides on environment. Hence the present study was undertaking on the Bio-management of Meloidogyne incognita in pumpkin.

\section{Materials and Methods}

A field experiment was carried out during the rabi season of 2019-20 in the Instructionalcum-Research Farm, Assam Agricultural University, Jorhat for the management of $M$. incognita on Pumpkin. Pumpkin cultivar Karbi-I, was selected for the present investigation. Trichoderma harzianum and mustard oil cake alone and in combinations were tested for their efficacy in management of root knot nematode in pumpkin. Carbofuran was used in the experiment as chemical check. T. harzianum and carbofuran were applied at the time of sowing while mustard cake was applied 15 days prior to sowing. The experiment was conducted in randomized block design with five treatments like T1-Trichoderma harzianum @20 kg/ha at time of sowing, T2- Mustard cake @ 750 $\mathrm{kg} / \mathrm{ha}$ applied 15 days prior to sowing, T3Trichoderma harzianum @ 10 kg/ha at time of sowing + Mustard cake @ $375 \mathrm{~kg} / \mathrm{ha}$ applied 15 days prior to sowing, T4Carbofuran@1 kg ail ha and T5-Control. Area of the experimental plot was divided in to 20 plots measuring $6 \mathrm{~m} \mathrm{x} 3 \mathrm{~m}\left(18 \mathrm{~m}^{2}\right)$ in each plot with four rows (Replication 4). A gap of $2 \mathrm{~m}$ was maintained between two plots. Different components of nematode management included in present study were applied to the plots according to the schedule of treatments. Pumpkin seeds were sown by keeping the spacing of $2 \mathrm{~m} \times 1.5 \mathrm{~m}$ between rows and plants respectively and a total of six 
pits were allotted to each plot. Irrigation, weeding and earthling's up of the plants were done whenever it required.

\section{The following observations were recorded}

\section{Initial nematode population}

Initially soil samples were collected randomly comprising 10-15 subsamples from the experimental plot, extract the soil sample through Cobb's sieving and decanting technique (Christie and Perry, 1951), and counted the nematode suspension by tally counting with the help of Hawksly counting dish.

\section{Yield of pumpkin}

Ripped and matured fruits were harvested whenever it was noticed and recorded per plot. The process of harvesting was continued till the crop is fully matured. At the end all yield data i.e., number of yields per plot, yield (kg/plot), was recorded in each plot and later on expressed in $\mathrm{q} / \mathrm{ha}$.

\section{Number of galls and egg masses per root system}

3 plants from each plot were selected and the number of galls and egg masses in each root system were recorded.

\section{Final nematode population}

For recording the final nematode population in soil, soil sample comprising of several sub samples were collected from different sites of each plot and mixed thoroughly and $200 \mathrm{cc}$ of it was drawn and processed by modified Cobb's sieving and decanting technique (Christie and Perry, 1951), and counted the nematode suspension by tally counting with the help of Hawksly counting dish.

\section{Statistical analysis}

Data obtained were analysed by following the Fisher's method of Analysis of variance by using WASP 1.0 software.

\section{Results and Discussion}

The data on the bio-management of Meloidogyne incognita in pumpkin in different treatments along with their C.D. values at 5 per cent probability level are presented in Table 1 and Fig. 1-5. In the field studies, it is observed that maximum number of fruits per plot, yield per plot and yield/ha were recorded in the chemical treatment i.e., Carbofuran@1 kgai/ha as compared to rest of the treatment. Similar, results were also recorded by Shanti (2016) said that application of chemical nematicide for the management of $M$. incognita in Pumpkin as well as Ash gourd produced maximum yield characters such as number of fruits per plant, yield per plant and yield/ha as than application of bioagents such as T. viride @ $2.5 \mathrm{~kg} / \mathrm{ha}$.

In the present investigation it was observed that combined application of T. harzianum @ $10 \mathrm{~kg} / \mathrm{ha}$ at the time of sowing and application of Mustard cake @ $375 \mathrm{~kg} / \mathrm{ha}$ at 15 days prior to sowing produced maximum number of fruits per plot, yield per plot and yield/ha than their individual application. The result of the present investigation is in accordance with Goswami et al., (2006) who reported that growth and yield characters were increased by the combined application of $T$. viride at 0.5 $\mathrm{kg} / \mathrm{ha}+$ mustard cake at $50 \mathrm{~kg} / \mathrm{ha}$ in tomato plant infected with $M$. incognita. Further, they concluded that instead of single application of T. viride at $0.5 \mathrm{~kg} / \mathrm{ha}$ and mustard cake at 50 $\mathrm{kg} / \mathrm{ha}$, the combined application produced maximum growth and yield characters of tomato. 
Table.1 Management of Meloidogyne incognita on Pumpkin cv Karbi-I

\begin{tabular}{|c|c|c|c|c|c|c|c|}
\hline \multirow[t]{2}{*}{ Treatments } & \multicolumn{2}{|c|}{ Yield characters } & \multirow{2}{*}{$\begin{array}{l}\text { Yield } \\
\text { (q/ha) }\end{array}$} & \multicolumn{4}{|c|}{ Nematode multiplication } \\
\hline & $\begin{array}{l}\text { No. of fruits } \\
\text { per plot }\end{array}$ & $\begin{array}{l}\text { Yield per } \\
\text { plot (kg) }\end{array}$ & & Egg masses & No. of galls & $\begin{array}{c}\text { INP/ } \\
200 \mathrm{cc} \text { of soil }\end{array}$ & $\begin{array}{c}\text { FNP/ } \\
200 \mathrm{cc} \text { of soil }\end{array}$ \\
\hline$T_{1}$ & $6.50^{\mathrm{c}}$ & $16.90^{\mathrm{d}}$ & 93.79 & $66.50^{\mathrm{b}}$ & $77.12^{\mathrm{c}}$ & & $254.29^{\mathrm{c}}$ \\
\hline $\mathbf{T}_{2}$ & $8.25^{\mathrm{b}}$ & $21.45^{\mathrm{c}}$ & 119.04 & $73.83^{b}$ & $86.25^{\mathrm{b}}$ & & $266.46^{\mathrm{b}}$ \\
\hline $\mathbf{T}_{3}$ & $9.75^{\mathrm{a}}$ & $25.35^{\mathrm{b}}$ & 140.07 & $56.42^{\mathrm{c}}$ & $63.33^{\mathrm{d}}$ & & $235.05^{\mathrm{d}}$ \\
\hline $\mathbf{T}_{4}$ & $10.75^{\mathrm{a}}$ & $27.95^{\mathrm{a}}$ & 155.12 & $46.71^{\mathrm{d}}$ & $59.67^{\mathrm{e}}$ & 350 & $214.37^{\mathrm{e}}$ \\
\hline$T_{5}$ & $5.00^{\mathrm{d}}$ & $12.50^{\mathrm{e}}$ & 69.37 & $135.17^{\mathrm{a}}$ & $115.62^{\mathrm{a}}$ & & $460.54^{\mathrm{a}}$ \\
\hline $\operatorname{SEd}( \pm)$ & 0.57 & 0.84 & & 4.3 & 1.61 & & 0.95 \\
\hline CD at 0.05 & 1.25 & 1.84 & & 9.44 & 3.51 & & 2.07 \\
\hline
\end{tabular}

$\mathrm{T}_{1}$ - Trichoderma harzianum @ $20 \mathrm{~kg} / \mathrm{ha}$ at time of sowing., $\mathrm{T}_{2}$ - Mustard cake @ 750kg/ha applied 15 days prior to sowing., $\mathrm{T}_{3}$ - Trichoderma harzianum @ $10 \mathrm{~kg} / \mathrm{ha}$ at time of sowing + Mustard cake @ 375 kg/ha applied 15 days prior to sowing., $\mathrm{T}_{4^{-}}$Carbofuran @ $1 \mathrm{~kg}$ ail ha and $\mathrm{T}_{5^{-}}$Control, INP- Initial Nematode Population and FNP- Final Nematode Population

Fig.1 Effect of different treatments on the number of fruits per plant of pumpkin infected by $M$. incognita under field condition

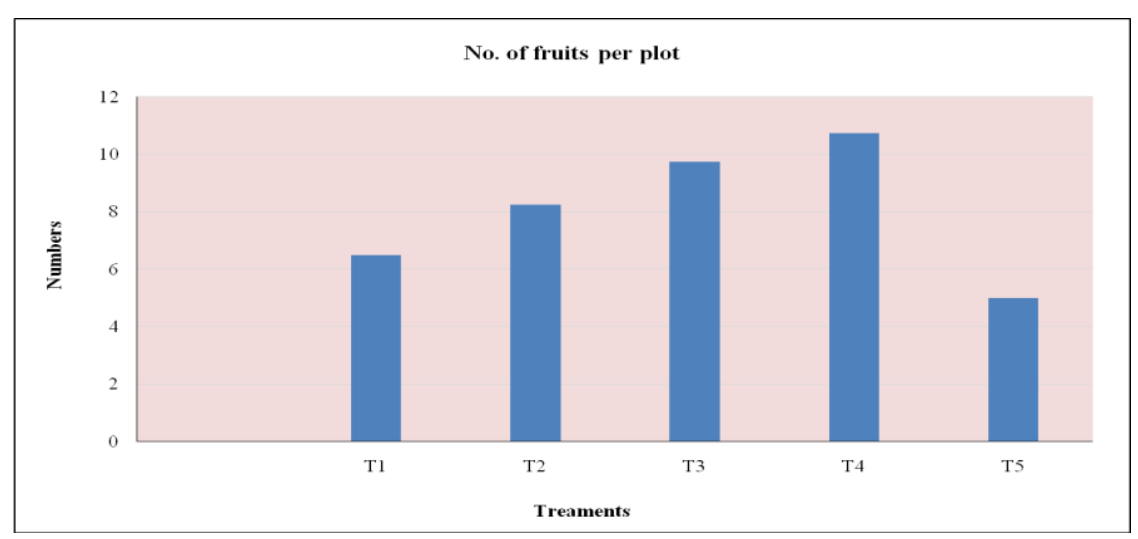

Fig.2 Effect of different treatments on yield characters of pumpkin infected by M. incognita under field condition

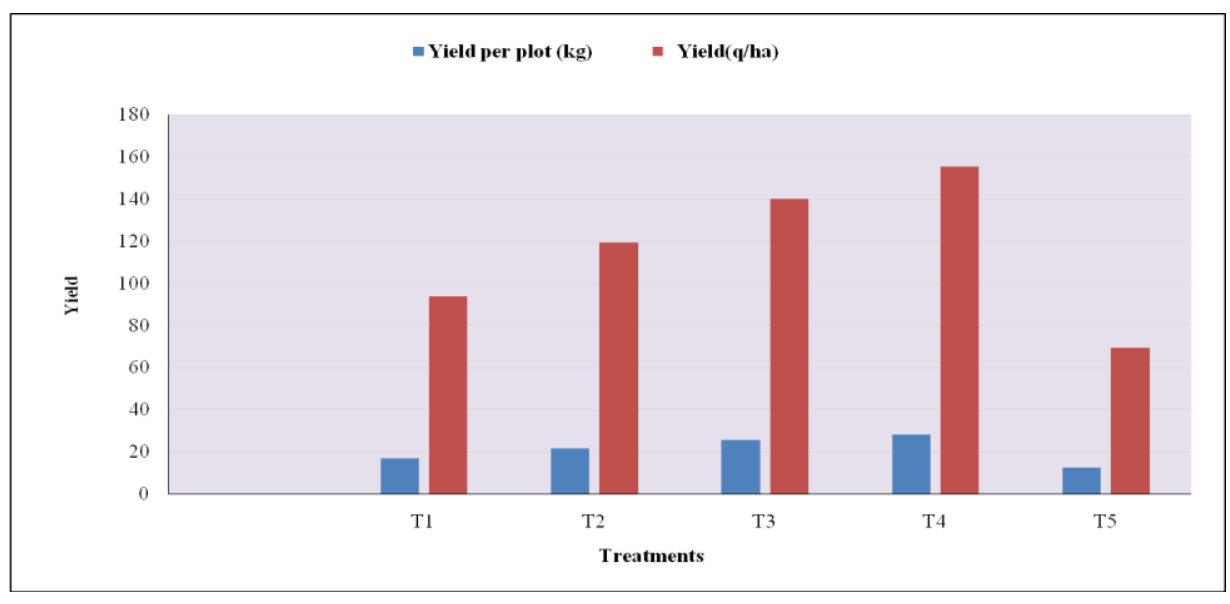


Fig.3 Effect of Trichoderma harzianum, mustard oil cake, combination of Trichoderma harzianum and mustard oil cake and carbofuran $3 \mathrm{G}$ on root growth of pumpkin

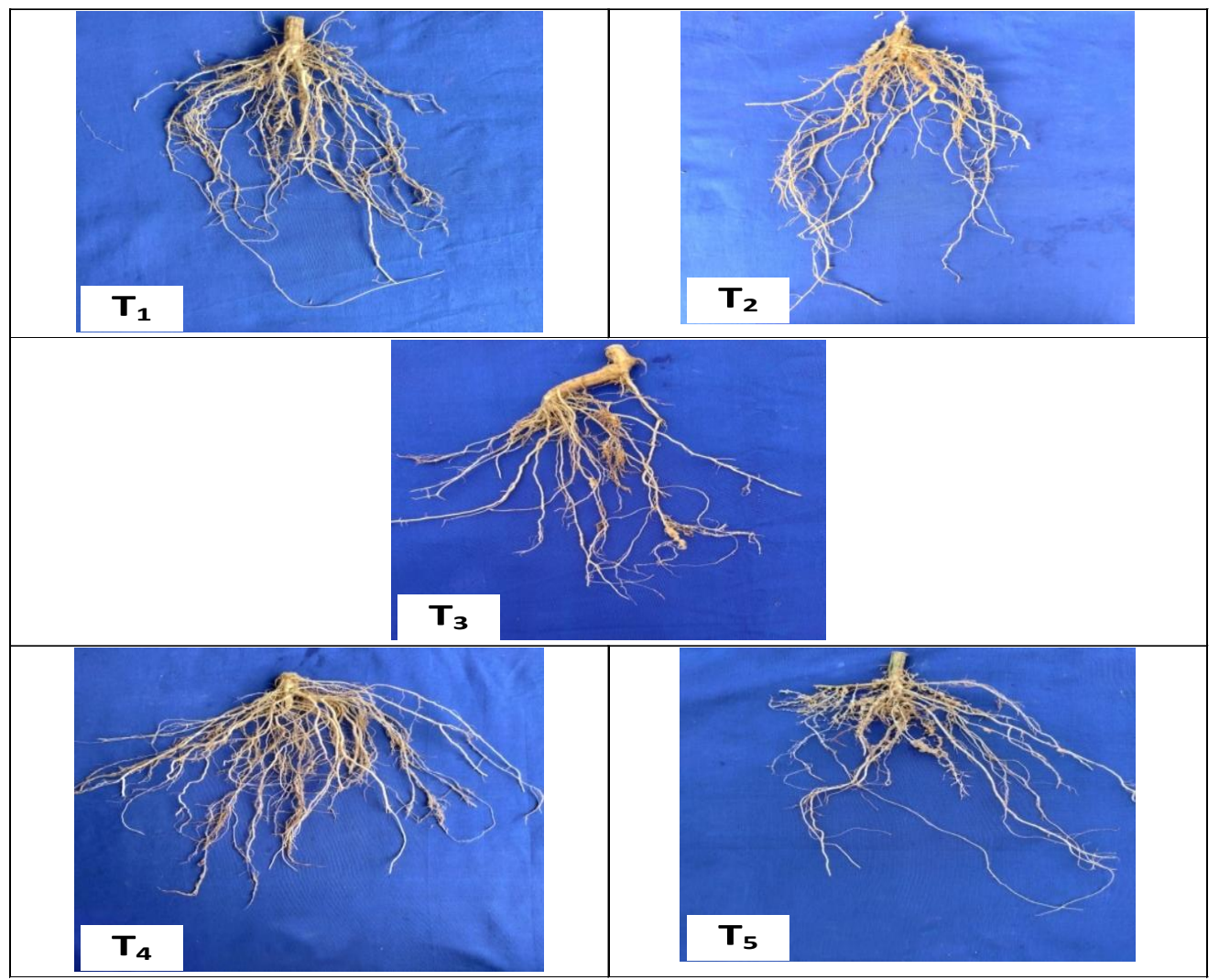

Fig.4 Effect of different treatments on number of galls and egg masses of M. incognita infected on Pumpkin cv Karbi-I under field condition

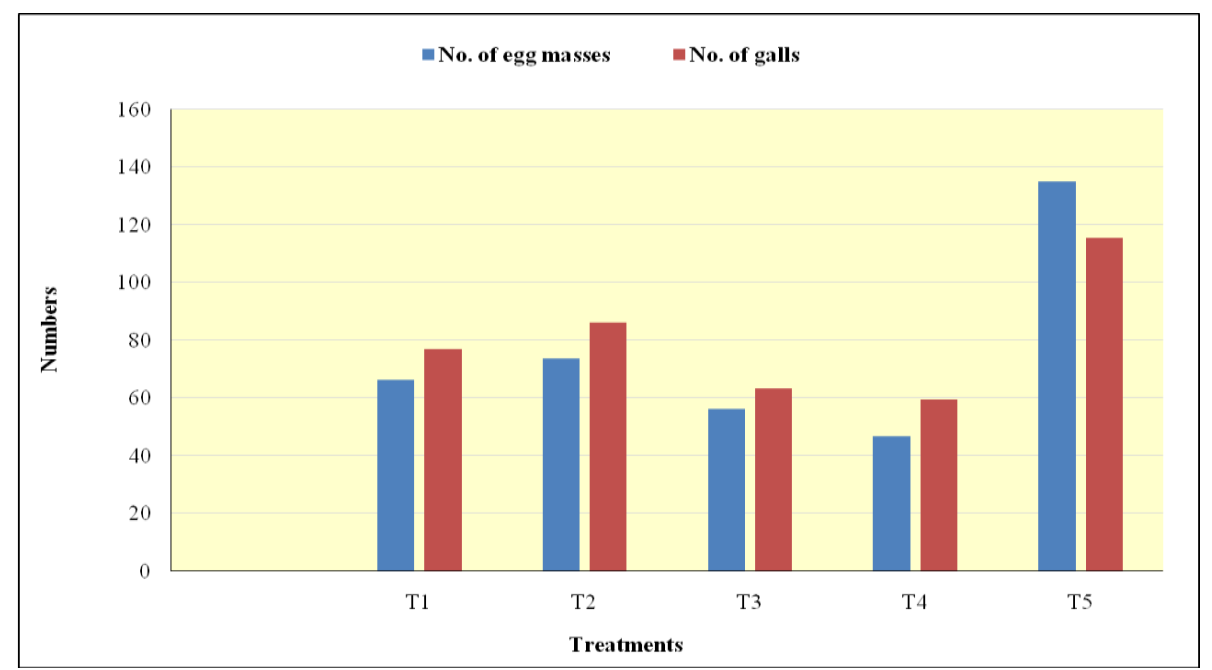


Fig.5 Effect of different treatments on final nematode population of $M$. incognita infected on Pumpkin cv Karbi-I under field condition

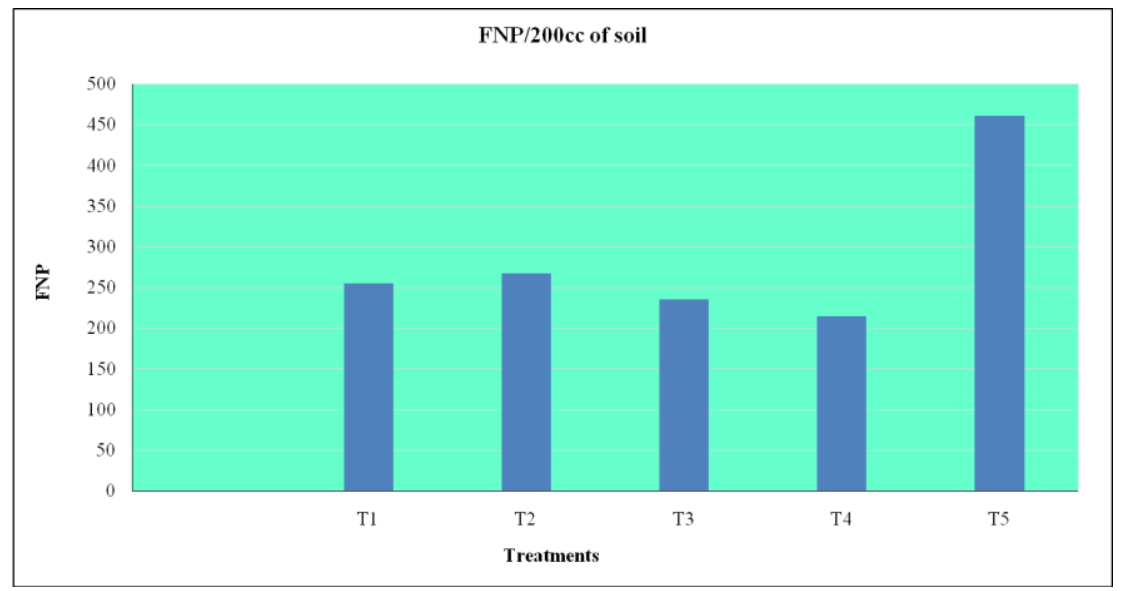

Individual application of Trichoderma harzianum@10 kg/ha and mustard cake@ $375 \mathrm{~kg} / \mathrm{ha}$ gave a higher $(6.50$ and 8.25 fruits per plot) number of fruits per plot, yield per plot and yield/ha as compared to untreated control. Similar, results were observed by Krishnaveni and Subramanian (2005) where in Trichoderma viride recorded significantly higher growth parameters and yield as compared to control in cucumber plants. Goswami et al., (2006) reported that individual application of $T$. viride @ $1 \mathrm{~kg} / \mathrm{ha}$ and mustard oil cake@100 kg/ha produced maximum yield of tomato as compared to control. Shanti (2016) who evaluated that application of T.viride @ $2.5 \mathrm{~kg} / \mathrm{ha}$ produced higher number of fruits per plant, yield per plant and yield/ha of pumpkin (cv Darsana) and Ash gourd (cv Archana) infected by $M$. incognita as compared to untreated control. Thus, support the result of the present experiment. Likewise, Thengal (2016) also reported that individual application of $T$. viride@20 kg/ha and mustard oil cake @ $750 \mathrm{~kg} / \mathrm{ha}$ produced higher yield as compared to control in tomato. The reason behind in increasing yield characteristic might be due to Trichoderma spp. are more rhizospheric competent and have their direct influence on either plant's growth or induction of plant defensive activity against pathogens (Shoresh et al., 2010; Hermosa et al., 2012; Brotman, 2013). Naserinasab et al., (2012) observed that application of Trichoderma spp. found to improve the plant growth parameters through increases in the enzymatic activities in treated Lycopersicon esculentum which ultimately reduced the biotic potentiality of plant parasitic nematode, $M$. incognita (Siddiqui and Akhtar, 2009) and support the result of the present investigation. Annapurna et al., (2018) reported that soil application of $T$. harzianum induce defence-related enzymatic activity like peroxidase (PO), polyphenol oxidase (PPO), phenylalanine ammonia lyase (PAL) and total phenol content in tomato against $M$. incognita and as a result improved the plant growth parameters. The reason for increased plant growth, yield and other parameters observed in the present study by Mustard oil cake might be due to release of micronutrients in rhizosphere during decomposition which enhance the microbial activity and that brings about increased conversion of $\mathrm{N}$ to nitrate form (Gunner, 1963). Ultimately, that caused increasing the rate of photosynthesis of plant and that increases the biomass of plants due to accumulation of more carbohydrate. Application of both organic amendments' 
along with biocontrol agents may bring about a synergistic effect in terms of either plant growth parameters or reduction of pathogen density and enhance the tolerant capacity of plant as compared to their individual application. In the present investigation it was observed that minimum number of galls, eggmasses and soil population of $M$. incognita were recorded in the chemical treatment i.e., Carbofuran @ $1 \mathrm{~kg}$ ai/ha as compared to rest of the treatment. Similar, results were also recorded by Mukhopadhyay et al., (2006) on pointed gourd, Kakati and Mahanta (2013) on cucumber. Anon. (2006) observed that carbofuran $3 \mathrm{G}$ was effective in reducing the nematode population. This report was also in agreement with Sitaramaiah and Viswakarma (1978) reported that spot application of the chemicals was superior.

Individual application of Trichoderma harzianum@10 kg/ha and mustard cake@ $375 \mathrm{~kg} / \mathrm{ha}$ resulted reduction in number of galls per root system, number of egg masses per galls and soil nematode population as compared to untreated control. Similar results were observed by Krishnaveni and Subramanian (2005) where in Trichoderma viride recorded significant reduction in nematode population in terms of number of galls per root system, number of egg masses per gall and soil nematode population as compared to control in cucumber plants. Shanti (2016) also noted that application of $T$. viride@2.5 kg/ha reduced number of galls per root system, number of egg masses per galls and soil nematode population in pumpkin (cv Darsana) and Ash gourd (cv Archana) infected by $M$. incognita as compared to untreated control. Momotaz et al., (2012) and Thengal (2016) reported similar result when mustard oil cake and bio agent $T$. harzianum were applied alone on tomato infested by $M$. incognita. Same trends of finding were also reported by Tripathi and Singh (2016) in tomato.
In the present investigation it was observed that combined application of T. harzianum @ $10 \mathrm{~kg} / \mathrm{ha}$ at time of sowing and application of Mustard cake@ $375 \mathrm{~kg} / \mathrm{ha}$ at 15 days prior to sowing reduced maximum number of galls per root system, number of egg masses per galls and soil nematode population than their individual application. The result of the present investigation is in accordance with Goswami et al., (2006) who reported that number of galls per root system, number of egg masses per galls and soil nematode population of $M$. incognita were decreased by the combined application of $T$. viride at 0.5 $\mathrm{kg} / \mathrm{ha}+$ mustard cake at $50 \mathrm{~kg} / \mathrm{ha}$ in tomato plant infected with $M$. incognita. They further concluded that combined application of $T$. viride and mustard oil cake was better than their individual treatments in increasing the crop yield and decreasing the $M$. incognita infestation on tomato. This may be attributed to the following reasons (i) accumulation of toxic substances such as phenolic compounds in roots (Alam et al., 1977) thereby hindering the penetration of nematodes (ii) release of certain fatty acids during decomposition of amendments which are nematotoxic as reported by Sayre et al., (1965). iii) $T$. harzianum showed parasitism on egg as well as larval of $M$. incognita (Kurulkar et al., 2019), iv) release of defence related enzyme molecules like peroxidase (PO), polyphenol oxidase (PPO), phenylalanine ammonia lyase (PAL) and Total phenol content in root that either provided the early resistance against plant pathogen or reduced the reproduction rate of pathogen (Annapurna et al., 2018).

Further, Goswami and Meshrum (1991) reported that the microbial activity in amended soil may lead to release of a wide variety of chemically different substances directly toxic to $M$. incognita. Decrease in root galling as well as population of root knot nematode in mustard cake amendment soil had been reported earlier by several workers 
(Saifullah and Gul, 1990; Khan et al., 1995; Bhagawati et al., 2000 and Anver, 2003).

\section{References}

Alam, M.M., Siddiqui, S.A. and Khan, A.M. (1977). Mechanism of control of plant parasitic nematodes as a result of the application of organic amendments to the soil. III. Role of phenols and amino acids in host roots. Indian J. Nematol. 7: 27-31.

Annapurna, M., Bhagawati, B. and Kurulkar, U. (2018). Biochemical mechanism of native fungal bioagents in the management of root-knot nematode Meloidogyne incognita on tomato. Intern. J. Curr. Microbiol. Appl. Sci. 7(11): 380-395.

Anonymous (2006). Quinquennial Report. AICRP on plant parasitic nematodes with integrated approach for their control. Assam Agricultural University, Department of Nematology, Jorhat.

Anonymous (2011). Biennial Report, AICRP on Nematodes in cropping systems, Jorhat, Assam. p. 18.

Anonymous (2018). Annual Report. National Horticulture Board of India. pp. 34-50.

Anver, S. (2003). Effect of different organic amendments with Paecilomyces lilacinus for the management of soil nematodes. Arch. Phytopathol. Pl. Protec. 36: 103-109.

Berkeley, M.J. (1855). Vibrio forming excrescences on the root of cucumber plants. Gard. Chron. 14: 220.

Bhagawati, B., Goswami, B.K. and Singh, C.S. (2000). Management of disease complex of tomato caused by $M$. incognita and Fusarium oxysporum f. sp. Licopersici through bioagent. Indian J. Nematol. 30(1): 16-22.

Brotman, Y. et al. (2013). Trichoderma-plant root colonization: escaping early plant defense responses and activation of the antioxidant machinery for saline stress tolerance. PLoS Pathogen. 9.

Christie, J. R., and V. G. Perry. 1951. Removing nematodes from the soil. Proc. Helm. Soc. Wash. 18: 106-108

Goswami, B.K., Pandey, R.K., Rathour, K.S., Bhattacharya, C. and Singh, L. (2006). Integrated application of some compatible biocontrol agents along with mustard oilseed cake and furadon on Meloidogyne incognita infection tomato. J. Zhejiang Univ. Sci. 7(11): 873-875.

Gunner, H.B. (1963). Nitrification by Arthrobacter globiformis. Nature, 197: 1127-1128.

Hermosa, R., Viterbo, A., Chet, I. and Monte, E. (2012). Plant-beneficial effects of Trichoderma and of its genes. Microbiol. 158: 17-25.

Irving, F. and Kerry, B.R. (1986). Variation between strains of the nematophagous fungus Verticillium chlamydosporium Goddard II. Factors affecting parasitism of cyst nematode eggs. Nematologica. 32: 474-485.

Kakati, N. (2012). Management of Meloidogyne incognita on cucumber. M.Sc. (Agri.) Thesis, submitted to Assam Agricultural University, Jorhat13.

Kakati, N. and Mahanta, B. (2013). Screening of cucumber cultivars against Meloidogyne incognita. Indian J. Nematol. 43(1): 105-106.

Khan, M., Ayub, M. and Jahangir, M. (1995). Efficacy of different organic amendments in the control of root-knot nematodes on tomato in Malakan Agency. Pakistan J. Nematol. 13: 2528.

Krishnaveni, M. and Subramanian, S. (2005). Root-knot nematodes of cucurbits and their management - A review. Agril. Rev. 26(2): 103-113.

Kurulkar, U., Bhagawati, B. and Neog, P.P. 
(2019). Biological control of Meloidogyne incognita by Trichoderma harzianum. Intern. J. Curr. Microbiol. Appl. Sci. 8(02): 2176-2188.

Momotaz, R., Islam, R., Ali1, M.E. and Siddique, S.S. (2012). Application of organic amendment and furadon $5 \mathrm{G}$ for the management of root-knot nematode of cucumber. Bangladesh J. Plant Pathol. 28(1\&2): 19-00.

Mukhopadhyay, A.K., Roy, K. and Panda, T.R. (2006). Evaluation of nematicides and neem cake for managing root-knot nematodes in pointed gourd, Trichosanthes dioica. Nematol. Medit. 34: 27-31.

Naserinasab, F., Sahebani, N. and Etebarian, H.R. (2012). Biological control of Meloidogyne javanica by Trichoderma harzianum BI and salicylic acid on Tomato. African J. Food Sci. 5(3): 276280.

Rodriguez-Kabana, R., Morgan-Jones, G. and Chet, I. (1986). Biological control of nematodes: Soil amendments and microbial antagonists. Plant and Soil, 100(1-3): 237-247.

Saifullah, Z.M. and Gul, A. (1990). Organic amendments as control of root-knot nematodes. Intern. Nematol. Net. Newsl. 1: 22-24.

Savitri, D. (2006). Studies on root-knot nematode, Meloidogyne spp. on cucurbitaceous vegetables. M.Sc. (Agri.) Thesis on Nematology, submitted to Acharya N.G. Ranga
Agricultural University, Hyderabad.

Shanthi, A. (2016). Management of root knot nematode, Meloidogyne incognita on Ash gourd (Benincasa hispida) and Pumpkin (Cucurbita pepo) using biocontrol agents. Ann. Plant Protec. Sci. 24(2): 399-401.

Shoresh, M., Harman, G.E. and Mastouri, F. (2010). Induced systemic resistance and plant responses to fungal biocontrol agents. Ann. Rev. Phytopathol. 48: 2143.

Siddiqui, Z.A. and Akhtar, M.S. (2009). Effects of antagonistic fungi and plant growth-promoting rhizobacteria on growth of tomato and reproduction of the root-knot nematode, Meloidogyne incognita. Australasian Pl. Path. 38: 22-28.

Singh, T. (2011). Investigations on root-knot nematodes (Meloidogyne spp.) on bottle gourd. M.Sc. (Agri.) Thesis on Nematology, submitted to Anand Agricultural University, Anand.

Sitaramaiah, K. and Viswakarma, S.N. (1978). Relative efficacy of selected non volatile nematicides in field for control of root-knot nematode of okra and tomato. India. J. Nematol. 8(1): 3242.

Thengal, P. (2016). Bio-management of rootknot nematode in organic tomato. M.Sc. (Agri.) Thesis, submitted to Assam Agricultural University, Jorhat13.

\section{How to cite this article:}

Lalhruaitluanga, Pc. and Koilash Hazarika. 2020. Bio-management of Meloidogyne incognita in Pumpkin. Int.J.Curr.Microbiol.App.Sci. 9(11): 762-770.

doi: https://doi.org/10.20546/ijcmas.2020.911.092 